\title{
Perlindungan Hukum Terhadap Bank Dari Tindak Pidana Pencucian Uang (Studi Kasus Putusan Nomor 81/PID.SUS/2019/PN.JPA)
}

\author{
Aris Dzilhamsyah \\ Magister Hukum Ekonomi, Fakultas Hukum, Universitas Indonesia \\ Depok, Indonesia \\ Email: arisdzilhamsyah@gmail.com
}

\begin{abstract}
Abstrak. Artikel ini membahas mengenai hubungan antara kegiatan pencucian uang dengan tindak pidana narkotika yang berkaitan dengan bank sebagai sarana pencucian uang. Dalam penelitian ini juga akan membahas mengenai perlindungan hukum terhadap bank serta bagaimana pencegahan kegiatan pencucian uang. Adapun dalam penelitian ini akan menggunakan sebuah kasus dengan nomor perkara 81/Pid.Sus/2019/PN.Jpa sebagai acuan. Penelitian ini adalah penelitian yuridis normatif dengan bentuk preskriptif, melakukan identifikasi pokok-pokok permasalahan yang hendak dibahas secara tuntas dengan norma hukum dalam peraturan perundang-undangan terkait. Hasil penelitian ini menemukan bahwa perlindungan hukum bagi bank yakni berasal dari tindakan preventif pihak bank sendiri dalam menerapkan prinsip Good Corporate Governance di Perusahaan, melaksanakan prinsip customer due diligence dan prinsip enhanced due diligence bagi calon nasabah maupun nasabah existing penyimpan dana. Selain itu bank harus selalu berkoordinasi dengan Pusat Pelaporan dan Analisis Transaksi Keuangan (PPATK) sebagai lembaga yang berwenang memberikan informasi atas harta kekayaan seseorang yang patut diduga adanya transaksi mencurigakan.
\end{abstract}

\section{Kata Kunci: Perlindungan Hukum, Bank, Tindak Pidana Pencucian Uang}

Abstract. This article convey about the relationship between money laundering and narcotics crimes and banks position as a means of money laundering. This research will also convey the legal protection of banks and how to prevent money laundering activities. In this study, we will use a case with case number 81 / Pid.Sus / 2019 / PN.Jpa as a reference. This research is a juridical normative research with prescriptive form, which identifies the main issues to be discussed thoroughly with the legal norms contained in the relevant laws and regulations. The results of this study found that legal protection for banks comes from preventive actions by the bank itself in applying the principles of good corporate governance principle, especially implementing the principles of customer due diligence andthe principle of enhanced due diligence for prospective customers and existing fund depositors. In addition, banks also must always coordinate with the Financial Transaction Reports and Analysis Center (PPATK) as the institution authorized to provide information on the assets of a person who should suspect a suspicious transaction.

\section{Keywords: Legal Protection, Bank, Money Laundering Crime}

\section{PENDAHULUAN}

\section{Latar Belakang}

Bank adalah badan usaha yang menghimpun dana dari masyarakat dalam bentuk simpanan dan menyalurkannya kepada masyarakat dalam bentuk kredit dan/atau bentuk-bentuk lainnya dalam rangka meningkatkan taraf hidup rakyat banyak. Bank berfungsi sebagai financial intermediary dengan kegiatan utama menghimpun dan menyalurkan dana masyarakat, serta memberikan jasa-jasa lainnya dalam lalu lintas pembayaran. Sebagai badan usaha, bank dituntut untuk mencari keuntungan dan berkewajiban menjaga kestabilan nilai uang, pembangunan, serta pertumbuhan ekonomi yang memiliki peran strategis dalam mencapai tujuan pembangunan nasional. 
Dengan meningkatnya kebutuhan jasa perbankan, disatu sisi memberikan manfaat bagi pelaksanaan pembangunan nasional, namun disisi lainnya menimbulkan risiko yang akan mempengaruhi kegiatan usaha bank. Risiko adalah ancaman atau kemungkinan atas suatu kejadian yang berdampak berlawanan dengan tujuan. Risiko acap kali dikaitkan dengan ketidakpastian akan kemungkinan yang terjadi dan berdampak terhadap hasil atau tujuan yang berbeda. Salah satu resiko kegiatan usaha bank adalah tindak pidana pencucian uang yang melibatkan bank sebagai penyedia jasa layanan keuangan. Tindak pidana Pencucian uang adalah the process by which one conceals the existence, illegal source, or illegal application of income and then disguises that income to make it appear legitimate. Pelaku tindak pidana pencucian uang dengan sengaja menyembunyikan atau menyamarkan asal usul harta kekayaan yang patut diduga berasal dari tindak pidana (perolehan sejumlah uang, sifatnya gelap, haram atau kotor) melalui bank, karena dianggap efektif melindungi pelaku dan harta hasil kekayaannya tersebut melalui investasi atau jasa perbankan lainnya.

Tindak pidana pencucian uang adalah kejahatan serius. Pelaku tindak pidana mengelabuhi asal usul harta kekayaan yang diperolehnya secara melawan hukum (seperti halnya, korupsi, penyuapan, narkotika dan tindak pidana lain sebagaimana diatur dalam Pasal 2 ayat 1 undang-undang nomor 8 tahun 2010 tentang pencegahan dan pemberantasan tindak pidana pencucian uang). Tindak pidana pencucian uang tersebut mengancam kegiatan usaha bank, stabilitas politik, keamanan, hukum dan perekonomian sebuah negara.

Di dunia Internasional, melalui International Offshore Banking Centers (IOBC), pelaku pencucian uang memanfaatkan kecanggihan jaringan pelayanan perbankan internasional untuk menampung rekening secret money. Pelaku pencucian uang memanfaatkan pasar keuangan karena pasar keuangan tidak memiliki geographic horizons, beroperasi 24 jam dan memiliki kecepatan secara elektronik melalui wire transfers sebagai metode pencucian uang (money laundering). Metode tersebut, dapat memindahkan dana dari aktivitas yang ilegal dari satu rekening ke rekening lainnya dalam lingkup domestik maupun internasional.

Di Indonesia menerapkan sistem devisa bebas, sehingga valuta asing bebas masuk di wilayah Indonesia. Hal tersebut berdampak positif bagi Indonesia karena investor asing dapat menanamkan modalnya secara langsung di Indonesia (foreign direct investment). Disisi lain, berdampak negatif karena modal yang diinvestasikan sulit diusut asal usulnya (berasal dari tindak pidana atau tidak). Kemudian, perkembangan pesat layanan bank di Indonesia menjadi sasaran bagi pelaku tindak pidana pencucian uang memanfaatkan fasilitas tersebut. Adapun menurut Pande Radja Silalahi, latar belakang terjadinya tindak pidana pencucian uang di Indonesia, diantaranya:

1. Di Indonesia, uang yang disimpan dalam bentuk deposito berjangka tidak dapat diusut asal usulnya, dengan sendirinya diputihkan dan halal;

2. Undang-undang perbankan yang berlaku di Indonesia memberikan peluang besar kepada Bank untuk merahasiakan kekayaan seseorang; dan, Indonesia menerapkan devisa bebas. Setiap orang yang pergi ke luar negeri dan masuk ke Indonesia, dengan leluasa membawa uang dalam jumlah yang tidak dibatasi, sehingga dimungkinkan untuk transfer atau terima uang darimana saja dan berapa pun jumlahnya.

Sehubungan dengan maraknya pelaku tindak pidana pencucian uang yang memanfaatkan fasilitas perbankan, penulis akan mengkaji tindak pidana pencucian uang dari tindak pidana narkotika dengan memanfaatkan fasilitas perbankan sebagai sarana menyamarkan atau menghilangkan jejak perolehan harta kekayaan yang dimilikinya. Studi kasus dalam penulisan ini adalah Putusan Nomor 81/Pid.Sus/2019/PN.JPA. 


\section{Rerumusan Masalah}

Berdasarkan uraian di atas, dapat dirumuskan beberapa pokok permasalahan yang akan dianalisis dalam bab-bab selanjutnya, diantaranya:

1. Bagaimanakah hubungan antara kegiatan pencucian uang dengan tindak pidana narkotika?

2. Bagaimanakah perlindungan hukum terhadap bank dan pencegahan kegiatan pencucian uang sebagaimana putusan No 81/Pid.Sus/2019/PN.Jpa?

\section{METODE PENELITIAN}

Penelitian ini menggunakan metode preskriptif yuridis normatif, yakni merupakan metode penelitian hukum kepustakaan atau penelitian hukum yang pelaksanaannya dilakukan dengan meneliti bahan pustaka yang ada. Dengan metode ini penulis akan melakukan penelitian dengan melakukan identifikasi pokok-pokok permasalahan yang hendak dibahas secara tuntas dengan norma hukum yang terdapat dalam peraturan perundang-undangan terkait.

Tipologi penelitian ini adalah penelitian preskriptif yakni penelitian yang bertujuan untuk mendapatkan saran-saran mengenai apa yang harus dilakukan untuk mengatasi masalah-masalah tertentu. Penulis memilih penelitian ini untuk mencari jawaban bagaimana perlindungan hukum terhadap bank dari pencegahan kegiatan pencucian uang dengan tindak pidana utama narkotika.

Jenis data yang digunakan dalam penelitian ini adalah data sekunder yaitu data yang diperoleh langsung melalui penelusuran literatur hukum dan kepustakaan. Data sekunder mencakup dokumen-dokumen resmi, buku-buku, hasil- hasil penelitian yang berwujud laporan, buku harian dan seterusnya. Pada umumnya data sekunder dalam keadaan siap terbuat dan dapat dipergunakan dengan segera, baik bentuk maupun isi data sekunder telah dibentuk dan diisi oleh peneliti-peneliti terdahulu terhadap pengumpulan, pengelolaan, analisa maupun konstruksi data. Data sekunder tidak terbatas oleh waktu maupun tempat. Data sekunder terdiri atas:
1. Bahan hukum primer, meliputi peraturan perundang-undangan, putusan hakim, perjanjian, dan dokumen langsung yang bersifat asli.

2. Bahan Hukum Sekunder yakni meliputi buku dan artikel. Bahan hukum sekunder yang digunakan dalam penelitian ini hasil penelitian hukum yang terdapat dalam buku-buku, jurnaljurnal, pendapat para ahli, hasil karya ilmiah, dan komentar-komentar dari kalangan hukum. Bahan hukum sekunder yang digunakan berisi mengenai isu-isu yang relevan dengan topik penelitian.

Bahan Hukum Tersier yakni meliputi kamus, peta, buku telepon, bibliografi, indeks, dan lain-lain. Bahan hukum tersier yang digunakan dalam skripsi ini, yaitu kamus hukum dan Kamus Besar Bahasa Indonesia (KBBI).

Dalam penelitian ini pengumpulan data sekunder dilakukan melalui studi kepustakaan. Pengumpulan data sekunder yang dilakukan melalui studi kepustakaan dengan menggunakan bahan-bahan dari buku, artikel yang dapat diakses secara online, dan data lainnya yang dapat mendukung penelitian ini. Studi kepustakaan dilakukan di beberapa tempat seperti perpustakaan Fakultas Hukum Universitas Indonesia.

Data yang telah diperoleh selanjutnya akan dianalisis secara kualitatif, artinya data yang telah didapat disusun secara sistematis dalam bentuk uraian atau penjelasan untuk menggambarkan hasil penelitian sehingga mudah dipahami agar dapat diinformasikan kepada orang lain. Menganalisa data secara kualitatif yaitu dengan pemahaman persepsi dan pemikiran sistematis Penulis terhadap data-data yang ada, dengan tujuan untuk menemukan jawaban terhadap permasalahan dalam penelitian ini.

\section{HASIL DAN PEMBAHASAN}

1. Hubungan Antara Kegiatan Pencucian Uang Dengan Tindak Pidana Narkotika

a. Kasus Posisi Putusan Nomor 81/Pid.Sus/2019/PN.Jpa 
Berikut kronologi singkat tindak pidana pencucian uang yang berasal dari tindak pidana narkotika, sebagaimana putusan nomor 81/Pid.Sus/2019/PN.Jpa:

1) Diawali tertangkapnya Christian Jaya Kusuma alias Kris alias Sancain, atas tindak pidana jual beli narkotika pada tanggal 9 November 2017, barang bukti narkotika golongan I jenis shabu seberat 800 (delapan ratus) gram.

2) Pada tanggal 10 November 2017, Fernando alias Emon dan Sudi Satria alias Babe (masuk daftar pencarian orang) menghubungi Terdakwa Nur Eka Suryani alias Anaagar dihubungkan dengan perwira di bagian narkoba untuk membantu kasus Sancain. Sancain adalah saudara temen Babe.

3) Terdakwa Ana menghubungi Koko Wahyudi, anggota polisi yang membantu kasus Sancain bekerjasama dengan Pri teman Koko Wahyudi di BNN.

4) Kemudian, dilanjutkan dengan pembicaraan sejumlah uang untuk melancarkan kasus Sancain antara Terdakwa Ana, Babe dan Koko Wahyudi.

5) Atas perintah Kokoh, Terdakwa Ana diminta membuat rekening baru di Bank BCA dan rekening baru tersebut atas nama Alfiah ibu kandung Terdakwa Ana, serta Terdakwa meminjam ATM BCA milik Tubagus Sadikin Zuhra.

6) Kedua rekening BCA tersebut digunakan oleh Terdakwa Ana untuk menerima transferan uang untuk penyelesaian kasus Sancain dari Babe.

7) Babe transfer uang kepada Terdakwa Ana melalui enam belas rekening BCA yang berbeda dengan jumlah uang transfer nilainya berbeda-beda dan total keseluruhan dari transferan Babe yang diterima Terdakwa Ana adalah Rp. 1.367.750.000,- (satu milyar tigas ratus enam puluh tujuh juta tujuh ratus lima puluh ribu rupiah). Rekening-rekening tersebut masuk dalam peredaran narkotika Sancain dan Terdakwa Ana mengetahui asal usul uang tersebut.

8) Kemudian, Terdakwa Ana mentransfer uang Babe kepada Koko Wahyudi secara bertahap. Pertama, melalui rekening BCA atas nama Tubagus Sadikin Zuhra sebesar Rp. 111.900,000,- (seratus sebelas juta Sembilan ratus ribu rupiah) dan kedua melalui rekening BCA atas nama Alfiah sebesar Rp. 678.000.000,(enam ratus tujuh puluh delapan juta rupiah).

9) Pada saat mengurusi perkara Sancai, Koko Wahyudi ditangkap oleh pihak kepolisian daerah Jawa Tengah dan didapati uang tunai sebesar Rp. 450.000.000,- (empat ratus lima putuh juta rupiah) yang merupakan uang transferan Terdakwa Ana, serta diduga berasal dari tindak pidana narkotika.

10) Uang sebesar Rp. 350.000.000,- (tiga ratus lima puluh juta rupiah) Terdakwa Ana tarik tunai dan dipergunakan untuk membeli mobil honda jazz tahun 2017 atas nama orang lain, yaitu Supraptin (tante Terdakwa Ana), serta sisanya habis dipergunakan untuk pembayaran asuransi all risk mobil honda jazz,membayar hutang dan kebutuhan sehari-hari Terdakwa Ana, serta pembuatan deposito di bank lain atas nama Alfiah ibu kandung Terdakwa.

11) Putusan Hakim adalah menyatakan bahwa Terdakwa Ana secara sah dan meyakinkan bersalah melakukan tindak pidana mentransfer dan membelanjakan atas harta kekayaan dengan tujuan menyamarkan asal usul harta kekayaan. Dipidana penjara selama 3 (tiga) tahun dan denda sejumlah Rp. 700.000.000,- (tujuh ratus juta rupiah) atau kurungan selama 2 (dua) bulan apabila denda tidak dibayarkan. 


\section{b. Ruang Lingkup Tindak Pidana Pencucian Uang}

Tindak pidana pencucian uang merupakan kejahatan yang mengancam stabilitas perekonomian dan integritas sistem keuangan, karena sifatnya yang berkelanjutan, yaitu memperoleh harta kekayaan dari tindak pidana kemudian dicuci agar tidak terlihat sebagai tindak pidana. Dalam konsep pencucian uang, menitikberatkan pada harta kekayaan yang diperolehnya, karena pada umumnya pelaku tindak pidana berusaha untuk menyembunyikan atau menyamarkan asal usul harta kekayaan yang merupakan hasil tindak pidana agar sulit untuk ditelusuri oleh aparat penegak hukum, sehingga dapat dimanfaatkan dengan leluasa untuk kegiatan yang sah ataupun tidak sah.

Patut diketahui, ruang lingkup pencucian uang dijabarkan lebih lanjut dalam undang-undang nomor 8 tahun 2010 tentang pencegahan dan pemberantasan tindak pidana pencucian uang, diantaranya: hasil tindak pidana berasal dari harta kekayaan yang diperoleh dari korupsi, penyuapan, narkotika, psikotropika, penyelendupan tenaga kerja, penyelundupan migran, di bidang perbankan, di bidang pasar modal, di bidang perasuransian, kepabeanan, cukai, perdagangan orang, perdagangan senjata gelap, terorisme, penculikan, pencurian, penggelapan, penipuan, pemalsuan uang, perjudian, prostitusi, di bidang perpajakan, di bidang kehutanan, di bidang kehutanan, di bidang lingkungan hidup, di bidang kelautan dan perikanan atau tindak pidana lain yang diancam dengan pidana penjara 4 (empat) tahun atau lebih. Harta kekayaan yang diketahui atau patut diduga akan digunakan dan/atau digunakan secara langsung atau tidak langsung untuk kegiatan terorisme, organisasi teroris, atau teroris perseorangan disamakan sebagai hasil tindak pidana.

\section{c. Tujuan Tindak Pidana Pencucian Uang}

Apabila pelaku tindak pidana melakukan pencucian uang, maka memungkinkan pelaku tindak pidana melakukan kegiatan sebagai berikut:

1) Menjauh dari kegiatan kriminal yang menghasilkan uang haram, sehingga dengan demikian akan lebih menyulitkan bagi otoritas untuk menuntut.

2) Menjauhkan uang haram itu dari aktivitas kriminal yang menghasilkan uang, sehingga menghindari dapat disita dan dirampasnya hasil kejahatan tersebut apabila pelaku yang bersangkutan ditangkap.

3) Menikmati manfaat dari fasilitas bank tanpa menimbulkan kecurigaan.

4) Menginvestasikan kembali uang haram itu pada kegiatan-kegiatan kriminal di masa yang akan datang atau ke dalam kegiatan yang sah.

d. Hubungan Antara Pencucian Uang Dengan Tindak Pidana Narkotika

Dalam International Narcotics Control Strategy Report (INCSR) yang dikeluarkan oleh Bureau for International Narcotics and Law Enforcement Affairs United States Departement of State, dinyatakan bahwa Indonesia dinilai lembaga dan sistem keuangannya terkontaminasi bisnis narkotika internasional dengan melibatkan jumlah uang sangat besar. Kejahatan peredaran gelap narkoba diyakini memiliki kaitan erat dengan pencucian uang. Sejarah perkembangan tipologi pencucian uang menunjukan bahwa perdagangan obat bius merupakan sumber yang paling dominan dan kejahatan asal (predicate crime) utama yang melahirkan kejahatan pencucian uang. Organized crime selalu menggunakan metode pencucian uang untuk menyembunyikan, menyamarkan atau mengaburkan hasil bisnis haram itu agar nampak seolah-olah merupakan hasil dari kegiatan yag sah, selanjutnya uang hasil jual beli narkoba yang telah dicuci digunakan untuk melakukan kejahatan serupa atau mengembangkan kejahatan baru.

Lahirnya rezim hukum internasional untuk memerangi kejahatan pencucian uang, antara lain dengan dikeluarkannya United Nations Convention Against Illicit Traffic in Narcotic drugs and Psychotropic Substances 
1988 (Vienna Convention 1988). Vienna Convention 1988 merupakan konvensi yang mengatur penegakan hukum di dalam mencegah dan memberantas lalu lintas perdagangan narkotika dan bahan psikotropika yang secara khusus mengatur masalah:

1) Penegasan dan perluasan lingkup kendali yang dititikberatkan pada illicit-trafficking by sea.

2) Penegasan mengenai yurisdiksi yang diperluas.

3) Ekstradisi.

4) Penyitaan (confiscation).

5) Hubungan timbal balik (mutual legal assistance).

Sejarah mencatat bahwa kelahiran rezim internasional untuk memerangi kejatan pencucian uang dimulai pada saat masyrakat internasional frustasi dengan upaya memberantas kejahatan gelap narkoba (berupa perdagangan gelap obat bius). Mengingat bahwa organized crime yang dihadapi memiliki karakteristik organisasi struktural yang solid, kejelasan pembagian wewenang, sumber pendanaan yang kuat dan jaringan kerja yang melintasi batas negara. Upaya yang dilakukan tidak hanya menangkap pelaku, melainkan penyitaan dan perampasan harta yang dihasilkan dari tindak pidana narkotika, serta membentuk regulasi anti pencucian uang.

Indonesia merupakan salah satu negara yang turut serta menandatangani Single Convention on Narcotics Drugs 1961 dan Vienna Convention 1988. Hal tersebut dilakukan sebagai upaya untuk menunjukkan kepada masyarakat di dalam dan di luar negeri adanya political will yang kuat dari pemerintah Indonesia memerangi maraknya peredaran gelap narkotika dan pencucian uang. Bentuk konkret dalam merespon isu tersebut di atas, Indonesia membentuk Badan Narkotika Nasional (BNN) dan peraturan perundang-undangan tentang narkotika, yakni Undang-undang Nomor 35 tahun 2009 tentang Narkotika sebagaimana disahkan pada tanggal 12 Oktober 2009, ditempatkan dalam Lembaran Negara Nomor 143 Tahun 2009 dan Tambahan Lembaran Negara Nomor 5062.

Selanjutnya merujuk pada Putusan Nomor 81/PID.SUS/2019/PN.JPA, penulis berpendapat bahwa Terdakwa Nur Eka Suryani alis Ana telah melakukan tindak pidana pencucian uang untuk menyamarkan hasil kekayaan yang diperoleh dari tindak pidana narkotika melalui dengan memanfaatkan fasilitas bank. Penulis sependapat dengan putusan Hakim yang memeriksa dan mengadili perkara tersebut, bahwa Terdakwa terbukti secara sah dan meyakinkan bersalah melakukan tindak pidana sebagaimana diatur dalam Pasal 3 Undang-undang Nomor 8 Tahun 2010 Tentang Pencegahan dan Pemberantasan Tindak Pidana Pencucian Uang, yakni:

"Setiap orang yang menempatkan, mengalihkan, membelanjakan, menghibahkan, menitipkan, membawa ke luar negeri, mengubah bentuk, menukarkan dengan mata uang atau surat berharga atau perbuatan lain atas harta kekayaan yang diketahuinya atau patut diduga hasil tindak pidana sebagaimana Pasal 2 ayat (1) dengan tujuan menyembunyikan atau menyamarkan asal usul harta kekayaan dipidana karena tindak pidana pencucian uang dengan pidana penjara paling lama 20 (dua puluh) tahun dan denda paling banyak Rp10.000.000.000,00 (sepuluh miliar rupiah)."

Adapun penjelasan terhadap unsurunsur Pasal tersebut di atas, sebagai berikut:

1) Unsur setiap orang (terpenuhi), Merujuk pada keterangan saksi, ahli, bukti surat, Terdakwa dan barang bukti di persidangan, Terdakwa mengetahui secara sadar harta kekayaan yang diperolehnya berasal dari tindak pidana narkotika dan Ana tidak berada di bawah pengampuan, tidak ada dasar pemaaf ataupun dasar pembenar atas tindak pidana pencucian uang tersebut, sehingga dapat dimintai pertanggungjawaban.

2) Unsur menempatkan, mengalihkan, membelanjakan, menghibahkan, menitipkan, membawa ke luar negeri, mengubah bentuk, menukarkan 
dengan mata uang atau surat berharga atau perbuatan lain atas harta kekayaan yang diketahuinya atau patut diduga dari hasil tindak pidana (terpenuhi). Dalam fakta persidangan, Terdakwa menerima uang yang diketahuinya dari hasil tindak pidana narkotika (masuk ke dalam harta kekayaan yang diperoleh dari tindak pidana sebagaimana Pasal 2 ayat 1 undang-undang nomor 8 tahun 2010 tentang pencegahan dan pemberantasan tindak pidana pencucian uang), kemudian mentransfer (perbuatan pemindahan uang dari penyedia jasa keuangan satu ke penyedia jasa keuangan lain) uang hasil tindak pidana tersebut secara bertahap ke rekening bank lain di dalam negeri atas nama Koko Wahyudi untuk menyelesaikan kasus tindak pidana narkotika dan membelanjakan (penyerahan sejumlah uang atas transaksi jual beli) uang tersebut untuk membeli mobil honda jazz tahun 2017 atas nama orang lain, pembayaran asuransi all risk mobil honda jazz, membayar hutang dan kebutuhan sehari-hari Terdakwa Terdakwa dan melakukan investasi berupa pembuatan deposito di bank lain atas nama orang lain.

3) Unsur menyembunyikan /menyamarkan asal usul harta kekayaan (terpenuhi). Dalam kasus, Terdakwa membuat rekening BCA atas nama Alfiah dan meminjam ATM milik orang lain untuk wadah menerima atau transfer uang. Adapun pola atau tahapan tindak pidana pencucian uang, diantaranya:

a) Placement

(penempatan).

Merupakan tahap pertama, yaitu pemilik uang tersebut menempatkan (mendepositokan) uang haram tersebut ke dalam sistem keuangan (financial system). Pada tahap ini, bentuk dari uang hasil kejahatan harus dikonversi untuk menyembunyikan asal usul yang tidak sah dari uang itu. Sebagai contoh, hasil dari perdagangan narkoba uangnya terdiri atas uanguang kecil dalam tumpukan besar dan lebih berat dari narkobanya, lalu dikonversi ke dalam denominisasi uang yang lebih besar. Lalu di depositikan ke dala rekening bank dan dibelikan ke instrument moneter seperti cheques, money orders dan lainnya. Bentuk kegiatan lainnya diantaranya menempatkan dana pada bank (lebih dari satu) diikuti dengan pengajuan kredit atau pembiayaan lain; menyetorkan uang pada bank atau perusahaan keuangan lain sebagai pembayaran kredit untuk mengaburkan audit trail; menyelundupkan uang tunai dari suatu negara ke negara lain; membiayai suatu usaha yang seoalah-olah sah atau terkait dengan usaha sah berupa kredit atau pembiayaan; dan membeli barangbarang berharga yang bernilai tinggi untuk keperluan pribadi atau sebagai hadiah kepada pihak lain yang pembayarannya dilakukan melalui bank.

b) Layering (transfer). Dalam tahap ini, pencuci berusaha memutuskan hubungan uang hasil kejahatan itu dari sumbernya, dengan cara memindahkan uang tersebut dari satu bank ke bank lain, hingga beberapa kali. Dengan cara memecah-mecah jumlahnya, dana tersebut dapat disalurkan melalui pembelian atau penjualan investment instrument. Mengirimkan dari perusahaan gadungan yang satu, ke perusahaan gadungan yang lain. Para pencuci uang juga melakukan dengan mendirikan perusahaan fiktif, bisa membeli alat transportasi, seperti pesawat, alat berat dengan atas nama orang lain. Bentuk kegiatannya, antara lain: transfer dana dari satu bank ke bank lainnya; simpanan tunai sebagai agunan 
untuk mendukung transaksi yang sah; dan memindahkan uang tunai lintas batas negara, baik melalui jaringan kegiatan usaha yang sah maupun shell company.

c) Integration (menggunakan harta kekayaan). Pencuci uang membawa kembali uangnya ke dalam sirkulasi dalam bentuk pendapatan bersih bahkan merupakan objek pajak dengan menggunakan uang telah menjadi halal (clean money) untuk kegiatan bisnis melalui cara dengan menginvestasikan dana tersebut ke dalam real estate, barang mewah, perusahaan-perusahaan. Pendapat lain mengenai integration, tertuang dalam Bunga Rampai Anti Pencucian Uang (Yunus Husein, halaman 6), dijelaskan bahwa integration (penggabungan) adalah proses pengalihan uang yang dicuci dari hasil kegiatan placement maupun layering ke dalam aktivitasaktivitas atau performa bisnis yang resmi tanpa ada hubungan atau links ke dalam bisnis haram sebelumnya. Pada tahap ini, uang haram yang telah diputihkan dimasukkan kembali ke dalam sirkulasi yang sesuai dengan aturan hukum dan telah berubah menjadi legal.

Merujuk kembali pada kasus, pola pencucian uang yang dilakukan oleh Terdakwa adalah menerima uang yang diketahuinya dari hasil tindak pidana narkotika dengan membuat rekening BCA atas nama Alfiah dan meminjam ATM milik orang lain untuk wadah menerima atau transfer uang (placement). Kemudian Terdakwa berupaya menjauhkan harta kekayaan yang diperoleh dari tindak pidana dengan cara mentransfer (perbuatan pemindahan uang dari penyedia jasa keuangan satu ke penyedia jasa keuangan lain) uang hasil tindak pidana tersebut secara bertahap ke rekening bank lain di dalam negeri atas nama Koko Wahyudi (layering). Setelah placement dan layering berjalan mulus, Terdakwa menggunakan harta kekayaannya secara aman, baik untuk kegiatan yang sah atau illegal (integration), yakni membeli mobil honda jazz tahun 2017 atas nama orang lain, pembayaran asuransi all risk mobil honda jazz, membayar hutang dan kebutuhan sehari-hari keluargaTerdakwa dan melakukan investasi berupa pembuatan deposito di bank atas nama orang lain menggunakan harta kekayaan hasil tindak pidana narkotika yang diterima dan diketahui oleh Terdakwa untuk membantu kasus Sancain karena ditangkap pada tanggal 9 November 2017 dengan barang bukti berupa narkotika golongan I jenis shabu seberat 800 (delapan ratus) gram sebagai upaya menyembunyikan atau menyamarkan harta kekayaan yang diketahui dan didapatinya dari tindak pidana pencucian uang.

\section{Perlindungan Terhadap Bank Dari Kegiatan Pencucian Uang \\ a. Pemanfaatan Bank Dalam Kegiatan Pencucian Uang}

Salah satu tindak pidana yang melibatkan bank adalah tindak pidana pencucian uang. Tindak pidana pencucian uang adalah kejahatan serius. Pelaku tindak pidana mengelabuhi asal usul harta kekayaan yang diperolehnya secara melawan hukum dan mengancam kegiatan usaha bank, serta dapat berujung pada potensi ketidakstabilan perekonomian Negara.Sehubungan dengan maraknya harta kekayaan yang diperoleh dari tindak pidana narkotika dan pencucian uang di Indonesia, bank menjadi pilihan untuk melancarkan kegiatan pencucian uang. Mengingat bank memiliki beranekaragam instrumen keuangan, pemanfaatan bank dalam kejahatan pencucian uang dapat berupa:

1) Menyimpan uang hasil tindak pidana dengan nama palsu (false identification);

2) Menyimpan uang di bank dalam bentuk deposito atau tabungan atau rekening atau giro dalam beberapa rekening, sehingga menghindari kecurigaan; 
3) Menukar pecahan uang hasil kejahatan dengan pecahan lainnya yang besar atau kecil;

4) Bank yang bersangkutan dapat diminta untuk memberikan kredit kepada nasabah pemilik simpanan dengan jaminan uang yang disimpan pada bank yang bersangkutan;

5) Menggunakan fasilitas transfer atau EFT (electronic fund transfer) dengan teknologi swift;

6) Melakukan transaksi ekspor-impor fiktif yang menggunakan sarana letter of creditdengan memalsukan dokumen-dokumen, bekerjasama dengan oknum pejabat terkait; dan,

7) Pendirian dan/atau pemanfaatan bank gelap.

Merujuk pada kasus, dalam memuluskan tindak pidana pencucian uang tersebut Terdakwa memanfaatkan fasilitas perbankan. Adapun fasilitas yang digunakan melalui transfer dana atau penempatan atau pemindahan dana hasil kekayaan dari tindak pidana narkotika melalui bank dengan cara menggunakan false identification. Modus yang digunakan Terdakwa adalah membuat rekening baru di Bank BCA atas nama orang lain (Alfiah ibu kandung Terdakwa) dan meminjam ATM BCA milik orang lain (Tubagus Sadikin Zuhra). Kedua produk bank tersebut dimanfaatkan oleh terdakwa untuk menempatkan dana dan memindahkan dana yang diketahuinya berasal dari tindak pidana narkotika.

Beragam fasilitas yang diberikan oleh bank, membuat pelaku tindak pidana pencucian uang menggunakan lembaga perbankan. Kemudian, ekonomi global yang terintegrasi juga membuat para pelaku tindak pidana pencucian uang lebih mudah melakukan transfer dengan cepat, sehingga identitas pelaku dan asal usul harta kekayaan lebih aman dari proses pengusutan. Kerugian atas tindak pidana pencucian uang tidak dirasakan secara langsung. Dapat dipastikan tindak pidana pencucian uang, erat kaitannya dengan bank sebagai corong utama perekonomi negara menghambat perekonomian Negara dan merugikan

masyarakat. Sejalan dengan pendapat John McDowell dan Gary Novis, menyatakan bahwa money laundering has potencially devastating economic, security and social consequences. Dengan adanya tindak pidana yang telah dilakukan oleh Terdakwa menjadi referensi bagi orang lain yang memiliki niat jahat untuk melakukan transaksi-transaksi yang ilegal menjadi legal karena telah terkontaminasi. Kemudian, menimbulkan fluktuasi tajam pada nilai tukar dan suku bunga, serta mengurangi kepercayaan publik terhadap lembaga keuangan yang berujung pada ketidakstabilan perekonomian Negara. Atas dasar tersebut, diperlukan upaya ataupun mitigasi risiko terhadap kegiatan usaha bank agar terhindar dari tindak pidana pencucian uang.

\section{Upaya Perlindungan Terhadap Bank Dari Tindak Pidana \\ a. Bank Menerapkan Prinsip 5C}

Prinsip ini dapat digunakan untuk mengenali calon debitur, seperti watak (character), modal (capital), kemampuan (capacity), kondisi ekonomi (condition of economic) dan jaminan (collateral).

1) Watak (Character). Watak dari calon debitur merupakan salah satu faktor yang harus dipertimbangkan dan merupakan unsur terpenting sebelum memutuskan untuk memberikan instrument keuangan kepada calon debitur. Dalam hal ini bank harus meyakini bahwa calon debiturnya memiliki reputasi baik, artinya selalu menepati janji dan tidak terlibat hal-hal yang berkaitan dengan kriminalitas.

2) Modal (Capital). Bank harus meneliti modal calon debitur, selain besarnya juga strukturnya. Hal ini diperlukan berkaitan dengan pemberian kredit untuk mengukur tingkat rasio likuiditas dan solvabilitasnya.

3) Kemampuan (Capacity). Bank harus mengetahui secara pasti atas kemampuan calon debitur dengan melakukan analisis usahanya dari waktu ke waktu. Pendapatan yang selalu meningkat diharapkan kelak mampu melakukan pembayaran 
kembali. Bila diperkiraka tidak mampu, bank berhak menolak permohonan dari calon debitur.

4) Kondisi Ekonomi (Condition of Economic). Kondisi ekonomi ini perlu menjadi sorotan bagi bank, karena akan berdampak secara positif atau negatif terhadap usaha calon debitur. Dapat terjadi dalam kurun waktu tertentu, misalnya pasaran tekstil yang biasanya menerima barang-barang tersebut menghentikan importnya.

5) Jaminan (Collateral). Jaminan yang diberikan oleh calon debitur, akan diikat suatu hak atas jaminan sesuai dengan jaminan yang diserahkan.

b. Bank Menerapkan Prinsip Prudential Banking

Salah satu prinsip terkait pengawasan bank yang diatur dalam Basel Committee on Banking Supervision (BCBS) 1997 sebagai upaya menerapkan prinsip kehati-hatian adalah Prudential Regulations and Requirements (persyaratan dan peraturan terkait prinsip kehati-hatian), terdapat 10 (sepuluh) poin yang dipersyaratkan dan diatur dalam Basel Committee on Banking Supervision (BCBS) 1997, diantaranya :

1) Pengawas bank harus mengatur secara bijak dan menerapkan prinsip kehati-hatian terkait kecukupan modal.

2) Menekankan evaluasi kebijakan sebuah bank, praktek dan prosedur berkaitan dengan pemberian pinjaman, investasi dan pengelolaan berkelanjutan dari pinjaman dari portofolio investasi.

3) Bank telah menetapkan dan mematuhi kebijakan yang memadai, praktek dan prosedur untuk mengevaluasi kualitas aset, kecukupan cadangan, kerugian pinjaman dan cadangan kerugian kredit.

4) Bank telah memiliki sistem informasi manajemen.
5) Bank memiliki prioritas utama untuk memberikan pinjaman atas dasar ketentuan pasar yang wajar dan panjang.

6) Bank memiliki kebijakan dan prosedur yang memadai untuk mengidentifikasi, memantau dan mengendalikan risiko transfer pemberi pinjaman dan kegiatan investasi lain.

7) Bank memiliki kebijakan dan prosedur yang memadai untuk mengidentifikasi, memantau dan mengendalikan risiko pasar.

8) Bank telah ada dalam jalur dan proses manajemen risiko yang komprehensif untuk mengidentifikasi, memantau dan mengendalikan risiko material dan menahan modal.

9) Bank telah berada di posisi pengendalian internal, memadai untuk sifat dan skala bisnis yang jelas.

10) Bank memiliki kebijakan yang memadai, praktek dan prosedur di tempat, termasuk menerapkan prinsip know your customer atau customer due diligence.

\section{c. Bank Menerapkan Customer Due Diligence}

Dengan

berkembangnya kompleksitas produk dan layanan jasa keuangan, serta meningkatnya penggunaan jasa teknologi informasi di industri jasa keuangan, maka semakin tinggi risiko penyedia jasa keuangan disalahgunakan sebagai sarana tindak pidana pencucian uang ataupun tindak pidana lainnya, sehingga diperlukan penerapan dan aturan Customer Due Diligence (CDD) sebagai upaya pendekatan berbasis risiko sesuai prinsip umum yang berlaku. Sebelumnya, istilah customer due diligence (CDD) dikenal dengan know your customer (KYC). Di Indonesia, awal penerapan customer due diligence (CDD) diatur dalamperaturan bank indonesia nomor 11/28/pbi tahun 2009 tentang penerapan program anti pencucian uang dan 
pencegahan pendanaan terorisme bagi bank umum.

Merujuk pada pasal 18 ayat 3 undang-undang nomor 8 tahun 2010 tentang pencegahan dan pemberantasan tindak pidana pencucian uang, dijelaskan bahwa penyedia jasa keuangan wajib menerapkan prinsip mengenali pengguna jasa (CDD) ketika melakukan hubungan usaha dengan pengguna jasa, ketika terdapat transaksi keuangan dengan mata uang rupiah dan/atau asing setara dengan Rp. 100.000.000,00 (seratus juta rupiah), terdapat transaksi keuangan mencurigkan terkait tindak pidana pencucian uang dan tindak pidana pendanaan terorisme atau diragukan kebenaran informasi yang dilaporkan pengguna jasa. Kemudian, pasal 1 angka 11 POJK nomor 12/POJK.01/2017 tentang penerapan program anti pencucian uang dan pencegahan pendanaan terorisme di sektor jasa keuangan, dijelaskan bahwa CDD adalah kegiatan identifikasi, verifikasi dan pemantauan yang dilakukan oleh penyedia jasa keuangan untuk memastikan transaksi sesuai dengan profil dan karakteristik calon nasabah atau nasabah. Kewajiban tersebut dilakukan pada saat melakukan hubungan usaha dengan calon nasabah terdapat transaksi keuangan dengan mata uang rupiah dan/atau mata uang asing yang nilainya paling sedikit atau setara dengan Rp. 100.000.000,00 terdapat transaksi transfer dana, indikasi transaksi keuangan mencurigakan terkait dengan pencucian uang dan/atau pendanaan terorisme atau penyedia jasa keuangan meragukan kebenaran informasi yang diberikan oleh calon nasabah, nasabah, penerima kuasa, dan/atau pemilik manfaat (beneficial owner).

\section{d. Bank Menerapkan Enhanced Due Diligence (EDD)}

Sebagaimana

rekomendasi

Financial Action Task Force (FATF) nomor 10, dijelaskan bahwa: where the risks of money laundering or terrorist financing are higher, financial institutions should be required to conduct enhanced
CDD measures, consistent with the risks identified. In particular, they should increase the degree and nature of monitoring of the business relationship, in order to determine whether those transactions or activities appear unusual or suspicious. Enhanced Due Diligence merupakan tingkatkan intensitas pemantauan untuk memastikan transaksi yang dilakukan tergolong tidak wajar atau mencurigakan.

\section{e. Berkoordinasi Dengan PPATK}

Pusat Pelaporan dan Analisis Transaksi Keuangan (PPATK) adalah lembaga intelijen di bidang keuangan yang memiliki bentuk administrative model. Dalam dunia internasional, lembaga intelijen di bidang keuangan ini lebih dikenal dengan nama generik Financial Intelligence Unit (FIU). Dalam rezim anti pencucian uang di Indonesia, PPATK merupakan elemen yang sangat penting karena merupakan national focal point dalam upaya mencegah dan memberantas tindak pidana pencucian uang. PPATK didirikan pada tanggal 17 April 2002, bersamaan disahkannya undang-undang nomor 15 Tahun 2002 tentang Tindak Pidana Pencucian Uang (TPPU). Keberadaan PPATK dimaksudkan sebagai upayauntuk ikut serta bersama dengan negara-negara lain memberantas kejahatan lintas negara yang terorganisasi seperti pencucian uang.Bank wajib untuk menjaga hubungan baik dengan PPATK, karena PPATK sebagai lembaga yang berwenang memberikan informasi atas harta kekayaan seseorang yang patut diduga adanya transaksi mencurigakan. Hal ini penting diketahui, karena PPATK dibentuk untuk mencegah TPPU.

\section{SIMPULAN}

Penulis menyimpulkan beberapa hal dari identifikasi permasalahan yang dituliskan, diantaranya :

1. Meningkatnya kebutuhan jasa perbankan, disatu sisi memberikan manfaat bagi pelaksanaan pembangunan nasional, 
namun disisi lainnya menimbulkan risiko yang akan mempengaruhi kegiatan usaha bank. Salah satu risiko bank adalah adanya tindak pidana pencucian uang. Pelaku tindak pidana pencucian uang dengan sengaja menyembunyikan atau menyamarkan asal usul harta kekayaan yang patut diduga berasal dari tindak pidana (perolehan sejumlah uang, sifatnya gelap, haram atau kotor) melalui bank, karena dianggap efektif melindungi pelaku dan harta hasil kekayaannya.

Penulis sependapat dengan hakim yang memeriksa dan mengadili perkara, bahwa Terdakwa terbukti secara sah dan meyakinkan bersalah melakukan tindak pidana sebagaimana diatur dalam Pasal 3 Undang-undang Nomor 8 Tahun 2010 Tentang Pencegahan dan Pemberantasan Tindak Pidana Pencucian Uang. Pola pencucian uang yang dilakukan oleh Terdakwa adalah menerima uang yang diketahuinya dari hasil tindak pidana narkotika dengan membuat rekening BCA atas nama Alfiah dan meminjam ATM milik orang lain untuk wadah menerima atau transfer uang (placement). Kemudian Terdakwa berupaya menjauhkan harta kekayaan yang diperoleh dari tindak pidana dengan cara mentransfer (perbuatan pemindahan uang dari penyedia jasa keuangan satu ke penyedia jasa keuangan lain) uang hasil tindak pidana tersebut secara bertahap ke rekening bank lain di dalam negeri atas nama Koko Wahyudi (layering). Setelah placement dan layering berjalan mulus, Terdakwa menggunakan harta kekayaanyang diperoleh, digunakan untuk membeli mobil honda jazz tahun 2017 atas nama orang lain, pembayaran asuransi all risk mobil honda jazz, membayar hutang dan kebutuhan seharihari keluarga Terdakwa dan melakukan investasi berupa pembuatan deposito di bank atas nama orang lain.

2. Tindak pidana pencucian uang adalah kejahatan serius. Pelaku tindak pidana mengelabuhi asal usul harta kekayaan yang diperolehnya secara melawan hukum dan mengancam kegiatan usaha bank, serta dapat berujung pada potensi ketidakstabilan perekonomian Negara. Bank menjadi pilihan untuk melancarkan kegiatan pencucian uang. Maraknya tindak pencucian uang yang dilakukan oleh pelaku atas harta kekayaan yang diperolehnya dari hasil tindak pidana, menjadi salah satu risiko bisnis yang dihadapi oleh bank. Adapun upaya yang dapat dilakukan untuk mencegah atau mitigasi atas tindak pidana pencucian uang diantaranya adalah menerapkan prinsip 5C (watak (character), modal (capital), kemampuan (capacity), kondisi ekonomi (condition of economic) dan jaminan (collateral)), menerapkan prinsip prudential banking, prinsip customer due diligence, prinsip enhanced due diligence dan menjaga hubungan baik dengan Pusat Pelaporan dan Analisis Transaksi Keuangan (PPATK) sebagai lembaga yang berwenang memberikan informasi atas harta kekayaan seseorang yang patut diduga adanya transaksi mencurigakan.

\section{SARAN}

1. Membenahi seluruh perangkat hukum dan peraturan perundang-undangan terkait dengan bank, pencucian uang dan narkotika. Dibutuhkan aturan yang memadai untuk memberikan kepastian bagi penegak hukum dalam menjerat kegiatan pencucian uang yang berasal dari tindak pidana narkotika dan komitmen penegak hukum menerapkan peraturan perundang-undangan yang ditetapkan.

2. Melakukan sosialisasi dan internalisasi kepada masyarakat perihal pentingnya peran bank dalam perekonomian suatu negara dan masyarakat, sehingga meminimalisir gerak pelaku tindak pidana yang akan memanfaatkan bank dalam melancarkan tindak pidana yang dilakukan.

3. Bank harus menjalankan prinsip-prinsip good corporate governance dalam menjalankan usahanya, sehingga memperhatikan penerapan 5C, CDD dan 
EDD. Mengingat prinsip tersebut menjadi acuan bagi bank dalam bertindak dan berhubungan dengan stakeholders.

\section{DAFTAR PUSTAKA}

Fuady, Munir. (1996). Hukum Perkreditan Kontemporer. Bandung: PT Citra Aditya Bakti.

Gultom, Santo Barri. (2015). Disparitas Pidana Dalam Kasus Tindak Pidana Pencucian

Indonesia. Undang-Undang Perubahan Atas Undang-Undang No. 7 Tahun 1992 Tentang Perbankan, UU No. 10 Tahun 1998, LN No. 182 Tahun 1998, TLN No. 3790.

McDowell, John and Gary Novis. The Cosquences of Money Laundering and Financial Crimes.http://www.usteas.gov. Diakses pada 15 Januari 2021.

Pakpahan, Rykcar G.B. (2006). Implementasi Prinsip Customer Due Diligince Pada Operasional Bank Umum Sebagai Upaya Pencegahan Kejahatan Pencucian Uang Di Indonesia. Jakarta: Tesis Magister Universitas Indonesia.

Peter Mahmud Marzuki. (2009). Penelitian Hukum, Jakarta: Kencana Prenada Media Group.

PPATK. Penilaian Risiko Indonesia Terhadap Tindak Pidana Pencucian Uang Tahun 2015.

http://www.ppatk.go.id/backend/assets/u ploads/20170911141103.pdf diakses pada 14 Januari 2020.

Siahaan. (2005). Pencucian Uang dan Kejahatan Perbankan. Jakarta: Sinar Harapan.

Silalahi, Pande Radja. (1998). Pencucian Uang dan Sistem Keuangan Internasional.Jurnal Hukum Bisnis Vol 3.

Soerjono Soekanto dan Sri Mamudji. (2009). Penelitian Hukum Normatif Suatu Tinjauan Singkat, Jakarta: Raja Grafindo Persada.

Soerjono Soekanto. (1986). Pengantar Penelitian Hukum, Cet.3, Jakarta: Penerbit Universitas Indonesia (UI-Press).

Sutedi, Adrian. (2008). Tindak Pidana Pencucian Uang. Bandung: Citra Aditya Bakti.

Tindak Pidana Pencucian Uang, UU No. 8 tahun 2010, LN No. 122 Tahun 2010, TLN No. 5164.
Uang Hasil Tindak Pidana Narkotika. JOM Fakultas Hukum Vol 2 No 2.

Husein, Yunus. (2007). Bunga Rampai Anti Pencucian Uang. Bandung: Books Terrace \& Library.

Idroes, N Ferry. (2008). Manajemen Risiko Perbankan Pemahaman Pendekatan Pilar Kesepakatan Basel II. Jakarta: PT RajaGrafindo Persada.

Indonesia, Undang-undang Pencegahan dan Pemberantasan

Tjahjono, Harry Achwan dan Totok Subjakto. (1993). Sistem Keuangan. Jakarta: Bank Indonesia.

Welling, Sarah N. (1989). Smurfs, Money Laundering and The Federal Criminal Law: The Crime of Structuring Transactions. Kentucky: Law Faculty Scholarly Articles. 